\title{
Assessment of Knowledge and Attitude among Faculty of Nursing Students Regarding Blood Donation
}

\section{1,Asmaa Yehia Youssef Ezeldain 2, Yosria El-Sayed Hossein3, Eman Sameh Mohammed, 4 Naglaa Mohammed Amein 4}

1. B. Sc in Nursing, Minia University, Egypt.

2. Professor of Community Health Nursing, Faculty of Nursing, Minia University, Egypt.

3. Assist Professor of Public Health and preventive Medicine, Faculty of medicine, Minia University, Egypt.

4. Lecturer of Community Health Nursing, Faculty of Nursing, Minia University, Egypt.

\begin{abstract}
Blood is the vital fluid which carries oxygen, nutrients, hormones, vitamins and antibodies to the tissues in the body and sends away the carbon dioxide and waste matters formed in the tissues from the body. Aim of the study: to assess knowledge and attitude among nursing students regarding blood donation. Research design: A descriptive research design was used for this study. Sample: A Stratified random sample, from first, second, third \& fourth academic year students in Faculty of Nursing Minia University. Data collection Tool: three tools were used in the study: Tool I: Demographic characteristics of nursing students and their previous history, Tool II: Knowledge Assessment Tool, and Tool III: Blood donation Attitude Scale. Results The current study found that more than half of nursing students aged between 20- 21 years with mean \pm SD $20.05 \pm 1.3$ years, about three quarter of them was female, more than one quarter of them were in $3^{\text {rd }}$ year academic years and more than two third of them comes from rural area. About more than half of nursing students had unsatisfactory knowledge about blood donation and most of them had positive attitude about blood donation. Conclusion: About more than one third of nursing students had satisfactory knowledge about blood donation and most of them had positive attitude about blood donation. Also, there was statistically significant difference between nursing students' knowledge and their age, academic years and attitude toward blood donation. Recommendation: Increase knowledge of nursing students about blood donation through making a seminar and workshop about it.
\end{abstract}

Keywords: Attitude, Blood donation, Knowledge, Nursing Students

\section{Introduction}

Blood is vital fluid that acts as nutrients transport throughout the body to perform its functions (Nataba, 2019). Blood donation occurs when a person has blood drawn and used for transfusions and/or made into biopharmaceutical medications by a process called fractionation (separation of whole-blood components). Donation may be of whole blood (WB) or of specific components directly (the latter called aphaeresis) (Frasiska et al., 2016) Blood donors can be differentiated into voluntary, family replacement, and paid donors. About 108 million blood donations are collected worldwide. More than half of these are collected in highincome countries, home to $18 \%$ of the world's population (Al-Mutairi et al., 2015).

Blood donation can be started safely from 17 years of age, so it is important that the young generation can be motivated to do this harmless task. In order to motivate students, first we should be aware of the knowledge, attitude and practices towards blood donation. Such studies are important to understand various factors that affect recruitment and retention of blood donors, to know the potential reasons that restrict them from doing this simple but lifesaving task, and to know the reasons that motivate the donors to donate blood. This can further help in planning proper and creative ways to recruit regular voluntary donors (Ugwu et al., 2019).

In a developing country like ours, lack of knowledge, blood donor recruitment and retention strategy and various misconceptions have resulted in a limited number of voluntary donors. This challenge can be tackled by adopting such recruitment methods that can overcome the misconceptions and also motivate the public to donate at an early age, so that they become lifelong voluntary donors (Ugwu et al., 2019). Some people believe that it is a national and religious duty while others stated that they would only donate if a family member or a friend is in need. (Al-Haqqan et al., 2016).

$P$ a g e | 39
A positive attitude among nursing students will bring change in the attitude of blood donation among patients during care and can be a core group to educate many friends and relative about the need for blood donation. There is also need to encourage, inspire, and motivate students to donate blood voluntarily and become a professional donor (Singh et al., 2015).

Community Health Nurses are clinically responsible for the donation session, with the care of the donors and the safety of the blood being their main priority. It also has the role of the nurses to supervise the donor careers that carry out a function similar to that of healthcare assistants in hospitals, and to ensure they deliver a first-class service. As well as providing clinical leadership for the teams nurses are also required to provide medical assessment expertise and have a critical role to play in the care before, during, and after donate blood and selection of donors as their suitability to certain level (Goda, 2017).

\section{Significance of the study}

"Blood connects us all" - was the theme for the World Blood Donor Day 14 June 2016. Blood transfusion is an important concern for the society, as it is lifesaving for patients with bleeding disorders, accidents, surgeries, inherited/acquired hematological diseases, and malignancies (Razdan et al., 2018).

In spite of, extensive efforts and a number of blood donation programs being organized worldwide, availability of adequate and safe blood still remains short to meet the increased demand in developing countries. The major challenge was recruitment of voluntary, non-remunerated blood donors. Literatures identified that many factors are responsible such as, lack of knowledge, negative attitudes, and inconvenience for facilities. Increase level of knowledge and 
positive attitude towards voluntary blood donation in young people is highest priority (Tadesse et al., 2018).

The World Health Organization (WHO) recommends that, for any country to meet the minimum demand for blood, collection should be at least from $1 \%$ of the population, on average, high income countries have 9 times higher donation rate compared to low-income countries (Elias et al., 2016).

\section{Aim of the Study}

This study aims to assess knowledge and attitude among nursing students regarding blood donation.

\section{Research Questions:}

1. What is the level of knowledge of nursing students regarding blood donation?

2. What is the attitude of nursing students regarding blood donation?

\section{Subjects and Methods \\ Research Design:}

A descriptive research design was used for this study.

\section{Setting:}

This study conducted in the Faculty of Nursing at Minia University for all grades. Total number of students in data collection year (2017- 2018) were one thousand four hundred seventy-five (1475).

\section{Subjects:}

A stratified random sample was collected, from first, second, third \& fourth academic year students of Faculty of Nursing.

\section{Sample size:} formula:

The sample size was calculated according to this

Formula: $n=t 2 \times(1-p) / m^{2}$.

\section{Description}

- $n=$ required sample size.

- $t=$ confidence level at 95\% (standard value of 1.96).

- $p=$ expected prevalence of students' blood donor $(50 \%)$.

- $m=$ margin of error at $5 \%$ (standard value of 0.05$)$.

- $n=(1.96)^{2} \times 0.8(1-0.8) /(0.05)^{2} . n=\sim 384$

Accordingly, the minimum sample size needed was 384 students, then we added additional number of students, 10 $\%$ of the calculated sample to guard against non-response so the sample was 422 , and it was distributed equally between 1st, 2nd, 3rd \& 4th academic year students of Faculty of Nursing.

\section{Tools for Data Collection:}

Tools for data collection consisted of three tools:

Tool I: A structured interview questionnaire designed by the investigator to collect data includes two parts:

Part 1: Demographic Characteristics of the student, it consisted of (4) items age, gender, class year, residence.
Part 2: Students previous history regarding blood donation, included (4) questions to assess previous history regarding blood donation : If the student ever donated blood, been asked questions before donating blood, how many times, when was the last time he/she donated blood and where was the last time he/she donated blood .

Tool II: Knowledge Assessment Tools: consisted of (31) closed ended questions to assess of student knowledge about blood donation such as: have attended seminars on blood donation, have information on blood donation, what is the amount of blood contained in the human body, what are the components of blood, what is the right age for blood donate, what is the appropriate weight for the person who donate blood, amount of blood a person can donate in a single time, blood group and types, different types of blood donors...etc.

Tool III: Blood donation Attitude Scale. This scale developed by Manikandan, et al., (2013). The scale included statements to assess students' attitude regarding blood donation. It consisted of 20 statements. All statements have response format (agree/ disagree or neutral) as: blood donation is charitable or voluntary, I think blood donation is a positive behavior, parents should be informed before donation of blood, I think blood donation can lead to anemia.

\section{Scoring system:}

Scoring system for tool II student's knowledge about blood donation, each correct response took two scores, wrong answer took one score and the not known response took (zero). The total score $<37.2$ scores (less than 60\%) was considered as unsatisfactory while score of 37.2 scores $(60 \%$ and more) was considered as satisfactory level

While scoring system for tool III Blood donation Attitude Scale, was carried out by using 3-point Likert scale. agree $=2$, neutral $=1$ disagree $=0$. Positive attitude statement was scored from two (for participants who agreed) to zero (for participants who disagreed). The opposite of this scoring was used for the negative attitude statements. Accordingly, the total score ranged between zero to 40 points. The total score $<$ 24 scores (less than $60 \%$ ) was considered as negative attitude while score 24 scores $(60 \%$ and more) was considered as positive attitude about blood donation.

\section{Validity and Reliability}

The tool tested for content validity by a jury of five experts in the field of the study to test the content validity of tools and necessary modifications was done. Reliability of the tools was performed to confirm its consistency by using Cornbrash's alpha test to tools II and III were $0.847 \& 0.901$ respectively

\section{Pilot Study}

Pilot study was carried out on $(10 \%)$ of sample 42 students from nursing students selected randomly from different academic years to check and ensure the clarity of Arabic questionnaires, identify the obstacle and problems that may encountered during data collection and to estimate the time needed to complete the questionnaires items and included in the study. 


\section{Data collection procedure}

An official permission was obtained from the Dean of Faculty of Nursing and Vice-dean for education and Student Affairs and from Academic Departmental Heads of Faculty of Nursing. An oral agreement was taken from the students who participate in the study after explaining the aim of the study. Confidentiality of obtained data was maintained and ensure for every student before starting data collection. Arabic translation of the study tool was done. Data was collected from the student at the beginning of academic year after permission of the nursing educators two days for each year's students during their clinical area.

The time consumed to fill the questionnaires was between 20 to 30 minutes. The investigator stayed with the students until the questionnaires were completed to ensure objectivity of the responses and to ensure that all item was answered. Data collection started at the beginning of October 2018 to the end of February 2019.

\section{Ethical and Legal Considerations}

A written initial approval was obtained from the Research Ethical Committee of the Faculty of Nursing, Minia
University, official permission was obtained to collect necessary data from the Dean of Faculty of Nursing and Vicedean for education and Student Affairs and from Academic Departmental Heads of Faculty of Nursing.

The Students were informed that their participation in this study is completely voluntary and there is no harm if they choose not to participate and no individual information is shared outside of the research. Oral informed consent was obtained from each participating nursing student after explaining the nature and benefits of the study. Each assessment sheet was coded, and student names not appeared on the sheets for the purpose of privacy and confidentiality.

\section{Statistical analysis}

The collected data were analyzed using Statistical Package for Social Sciences (SPSS) IBM 25 for windows. Data were collected, tabulated. Quantitative data were presented by mean (standard deviation), while qualitative data presented by frequency distribution. The Chi-square test was used to compare between proportions. Test of significance were considered as: insignificant (NS) P.value $\geq 0.05$, * significant $\mathrm{P}$.value $<0.05$, and $* *$ highly significant $\mathrm{P}<0.01$.

\section{Results}

Table (1): Socio Demographic characteristics of the studied nursing students $(n=422)$.

\begin{tabular}{|c|c|c|}
\hline Demographic Characteristics & No. & $\%$ \\
\hline \multicolumn{3}{|l|}{ Age / years } \\
\hline $18-19$ & 131 & 31.0 \\
\hline $20-21$ & 230 & 54.5 \\
\hline $22-23$ & 61 & 14.5 \\
\hline Mean \pm SD & \multicolumn{2}{|c|}{$20.05 \pm 1.3$ years } \\
\hline \multicolumn{3}{|l|}{ Sex } \\
\hline Male & 109 & 25.8 \\
\hline Female & 313 & 74.2 \\
\hline \multicolumn{3}{|l|}{ Academic years } \\
\hline $1^{\text {st }}$ year & 107 & 25.4 \\
\hline $2^{\text {nd }}$ year & 115 & 27.3 \\
\hline $3^{\text {rd }}$ year & 116 & 27.5 \\
\hline $4^{\text {th }}$ year & 84 & 19.9 \\
\hline \multicolumn{3}{|l|}{ Residence } \\
\hline Urban & 132 & 31.3 \\
\hline Rural & 290 & 68.7 \\
\hline
\end{tabular}

Table 1 shows that $54.5 \%$ of the studied nursing students aged between 20 - 21 years with mean \pm SD $(20.05 \pm 1.3)$ years, $74.2 \%$ of them was female, $27.5 \%$ of them was in 3 rd year academic year and $68.7 \%$ of them comes from rural area.

Table (2): Frequency distribution of the studied nursing students regarding previous history of blood donation $(\mathrm{n}=422)$.

\begin{tabular}{|c|c|c|}
\hline Previous blood donation & No. & $\%$ \\
\hline Yes & 66 & 15.6 \\
\hline No & 356 & 84.4 \\
\hline \multicolumn{3}{|l|}{ If no, the causes are $(n=356)$} \\
\hline Anemia & 144 & 40.4 \\
\hline Not have a chance & 105 & 29.5 \\
\hline Fear from infection & 38 & 10.7 \\
\hline Hypotension & 6 & 1.7 \\
\hline Fear from needle & 42 & 11.8 \\
\hline Thinness & 21 & 5.9 \\
\hline \multicolumn{3}{|l|}{ If yes, number of donations } \\
\hline One time & 49 & 74.2 \\
\hline More than one & 17 & 25.8 \\
\hline \multicolumn{3}{|l|}{ Were asked a question before donation } \\
\hline Yes & 44 & 66.7 \\
\hline No & 22 & 33.3 \\
\hline \multicolumn{3}{|l|}{ If yes it was $(n=44)$} \\
\hline Previous donate, when, $\mathrm{Hb}$ level & 18 & 40.9 \\
\hline Have chronic illness, take antibiotics, take fluids before donation & 13 & 29.5 \\
\hline Last time of donation, have blood disease & 5 & 11.4 \\
\hline Have any virus disease & 4 & 9.1 \\
\hline Suffer from anemia & 4 & 9.1 \\
\hline \multicolumn{3}{|l|}{ Causes of blood donation $(n=66)$} \\
\hline Help people & 43 & 65.2 \\
\hline Volunteer & 2 & 3.0 \\
\hline
\end{tabular}


Minia Scientific Nursing Journal (Print - ISSN 2537-012X) (Online - ISSN 2785-9797) Vol. (8) No. (1) December 2020

\begin{tabular}{|l|c|c|}
\hline Previous blood donation & No. & $\mathbf{\%}$ \\
\hline Help patients and reassure my self & 10 & 15.2 \\
\hline Surgery for my relative & 11 & 16.6 \\
\hline Last time of donation $(\mathbf{n}=\mathbf{6 6})$ & & \\
\hline Less than one year & 38 & 57.6 \\
\hline More than one year & 28 & 42.4 \\
\hline Place of donation $\mathbf{( n = 6 6 )}$ & & \\
\hline In the hospital & 15 & 22.7 \\
\hline In blood bank & 6 & 9.1 \\
\hline In blood donation car & 45 & 68.2 \\
\hline
\end{tabular}

Table 2 presents that $84.4 \%$ of the studied nursing students don't previous blood donation, $40.4 \%$ of them the main causes of its was anemia. Concerning number of donations $74.2 \%$ of nursing student donated one time, $66.7 \%$ of them reported they asked before donation, and $40.9 \%$ the main question was about level of hemoglobin. Regarding causes of blood donation $65.2 \%$ of them was to help the people, $57.6 \%$ of them last time of donation was less than one year and $68.2 \%$ of them donated in blood donation car.

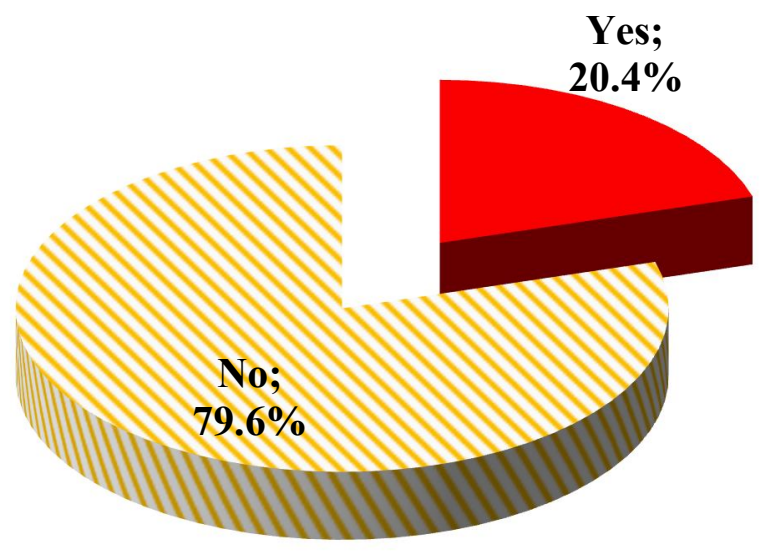

Figure (1): Distribution of the studied nursing students regarding attended previous workshop $(n=422)$.

Figure (1): demonstrates that $20.4 \%$ of the studied nursing students attended previous workshop, and $79.6 \%$ of them don't attended any previous workshop.

Table (3.a): Frequency distribution of the studied nursing students regarding their general knowledge about blood donation $(n=422)$.

\begin{tabular}{|c|c|c|}
\hline General knowledge & no. & $\%$ \\
\hline Amount of blood in the body & 345 & 81.8 \\
\hline Components of blood & 414 & 98.2 \\
\hline Knowledge about ABO blood type & 388 & 98.2 \\
\hline Methods of measuring $\mathrm{Hb}$ level & 7 & 1.7 \\
\hline How much blood is removed during a donation cession? & 285 & 67.5 \\
\hline Advantages of blood donation & 319 & 75.6 \\
\hline Precautions before blood transfusion & 372 & 88.2 \\
\hline Precautions after blood transfusion & 399 & 94.5 \\
\hline
\end{tabular}

Table 3.a shows that $98.2 \%$ of the studied nursing students answered correctly components of blood, $94.5 \%$ and $88.2 \%$ of them answered correctly precautions after and before blood transfusion respectively, but $36.3 \%$ of them know their blood group.

Table (3.b): Frequency distribution of nursing students regarding their knowledge about donor eligibility $(n=422)$.

\begin{tabular}{|l|c|c|}
\hline Knowledge about donor eligibility & no. & \% \\
\hline What are the age limits of the donor? & 42 & 10.0 \\
\hline What is the suitable weight of the donor? & 115 & 27.3 \\
\hline What is the minimal interval between two male donations by a person? & 184 & 43.6 \\
\hline What is the minimal interval between two female donations by a person? & 163 & 38.6 \\
\hline Level of Hb for male donation & 186 & 44.1 \\
\hline Level of Hb for female donation & 207 & 49.1 \\
\hline Can a pregnant woman donate? & 412 & $\mathbf{9 7 . 6}$ \\
\hline Can a female during menstruation donate? & 26 & 6.2 \\
\hline Can donate with whole blood & 195 & 46.2 \\
\hline
\end{tabular}


Minia Scientific Nursing Journal (Print - ISSN 2537-012X) (Online - ISSN 2785-9797) Vol. (8) No. (1) December 2020

\begin{tabular}{|l|c|c|}
\hline Knowledge about donor eligibility & no. & \% \\
\hline Can donate with platelets only & 88 & 20.9 \\
\hline Normal blood pressure for donated person $(\mathrm{mmHg})$ & 399 & $\mathbf{9 4 . 5}$ \\
\hline Laboratory investigations before donation & 362 & 85.8 \\
\hline Laboratory investigations after donation & 91 & 21.6 \\
\hline Can a person on medications for chronic diseases donate? & 392 & $\mathbf{9 2 . 9}$ \\
\hline Psychiatric patients can donate & 257 & 60.9 \\
\hline Person with previous surgery can donate & 215 & 50.9 \\
\hline Contraindications of donation & 331 & 78.4 \\
\hline
\end{tabular}

Table 3.b presents that $97.6 \%$ of nursing students answered correctly pregnant women can donated or not, $94.5 \%$ of them know normal blood pressure for donated person and $929 \%$ of them answered correctly if a person on medications for chronic disease donate or not.

Table (3.c): Frequency distribution of nursing students regarding their knowledge about consequences of donation $(n=422)$.

\begin{tabular}{|l|c|c|}
\hline Knowledge about consequences of donation & no. & \% \\
\hline There are complications after donation & 94 & 22.3 \\
\hline Compensated the donated blood (plasma) & 137 & 32.5 \\
\hline Compensated the donated blood (RBCs) & 141 & 33.4 \\
\hline Compensated the amount of iron lost during donation & 139 & 32.9 \\
\hline
\end{tabular}

Table 3.c shows that $33.4 \%$ of nursing students answered correctly time of compensated red blood cells, $32.9 \%$ and $32.5 \%$ of them answered correctly time of compensated the amount of iron lost during donation and plasma

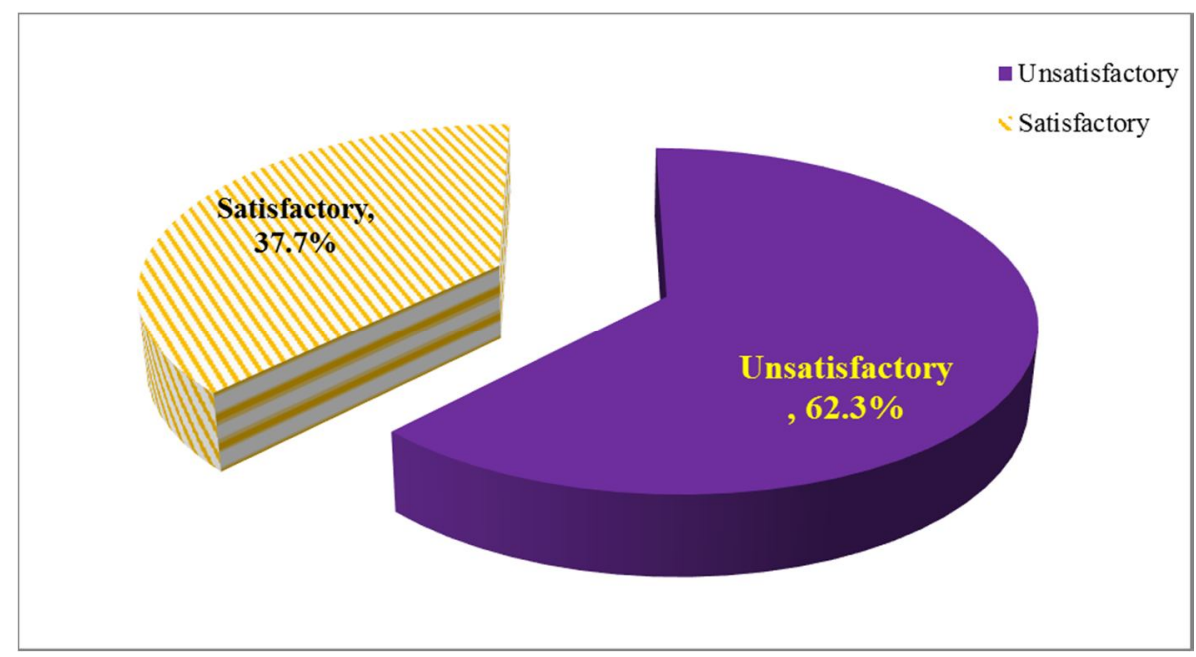

Figure (2): Frequency distribution of the studied nursing students regarding their total knowledge level about blood donation $(n=422)$.

Figure (2): illustrates that more than one third (37.7\%) of the studied nursing students had satisfactory knowledge about blood donation and $62.3 \%$ of them had unsatisfactory knowledge.

Table (4): Frequency distribution of the studied nursing students regarding their attitude about blood donation $(n=422)$.

\begin{tabular}{|c|c|c|c|c|c|c|}
\hline \multirow[t]{2}{*}{ Blood donation attitude } & \multicolumn{2}{|c|}{ Agree } & \multicolumn{2}{|c|}{ Neutral } & \multicolumn{2}{|c|}{ Disagree } \\
\hline & no. & $\%$ & no. & $\%$ & no. & $\%$ \\
\hline Volunteer work & 412 & 97.6 & 6 & 1.4 & 4 & .9 \\
\hline Positive behaviors & 399 & 94.5 & 14 & 3.3 & 9 & 2.1 \\
\hline Unnecessary & 66 & 15.6 & 334 & 79.1 & 22 & 5.2 \\
\hline Inform parents before donation & 326 & 77.2 & 67 & 15.9 & 29 & 6.9 \\
\hline Lead to anemia & 178 & 42.2 & 171 & 40.5 & 73 & 17.3 \\
\hline Ready to continuous donation & 163 & 38.6 & 193 & 45.8 & 66 & 15.6 \\
\hline Feel empathy with the patient need blood donation & 367 & 87.0 & 32 & 7.6 & 23 & 5.5 \\
\hline Physically strong people only can donate & 137 & 32.5 & 253 & 60.0 & 32 & 7.6 \\
\hline Ready to continuous donation in emergency situation & 341 & 80.8 & 44 & 10.5 & 37 & 8.7 \\
\hline Improve the health & 396 & 70.1 & 48 & 11.4 & 78 & 18.5 \\
\hline Check blood before donation limit increasing the infectious diseases & 380 & 90.0 & 29 & 6.9 & 13 & 3.1 \\
\hline Fear from it & 221 & 52.4 & 174 & 41.2 & 27 & 6.4 \\
\hline Increase chance for infectious disease with it & 266 & 63.0 & 99 & 23.5 & 57 & 13.5 \\
\hline Encourage the volunteer & 322 & 76.3 & 78 & 18.5 & 22 & 5.2 \\
\hline Deficiency knowledge is the main causes of limit blood donation & 328 & 77.7 & 64 & 15.2 & 30 & 7.1 \\
\hline May occur complications during and after donation & 311 & 73.7 & 55 & 13.0 & 56 & 13.3 \\
\hline Take it from volunteer only & 221 & 52.4 & 136 & 32.2 & 65 & 15.4 \\
\hline Take long time & 75 & 17.8 & 279 & 66.1 & 68 & 16.1 \\
\hline Discover correct information about the health & 349 & 82.7 & 39 & 9.2 & 34 & 8.1 \\
\hline Lead to psychological changes & 65 & 15.4 & 253 & 60.0 & 104 & 24.6 \\
\hline
\end{tabular}


Table 4 shows that $97.6 \%$ of the studied nursing students agreed with blood donation is a volunteer work, $94.5 \%$ of them agreed with it's a positive behavior, $90.0 \%$ of them agreed with they checked blood before donation limit increasing the infectious disease and $87.0 \%$ of them agreed with they felled empathy with the patient need blood donation.

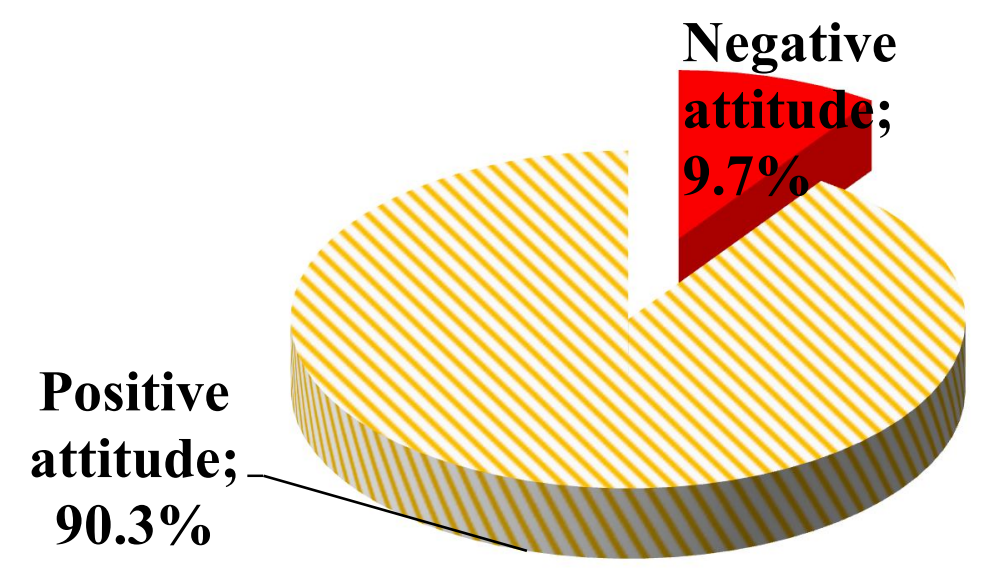

Negative

Figure (3): Frequency distribution of the studied nursing students regarding their attitude about blood donation $(\mathrm{n}=422)$.

Figure (3): illustrates that the majority $(90.3 \%)$ of the studied nursing students had positive attitude towards blood donation and $9.7 \%$ of them had negative attitude.

Table (5): Relations between the studied nursing student's total knowledge levels and their demographic data (n=422).

\begin{tabular}{|c|c|c|c|c|c|c|}
\hline \multirow[t]{2}{*}{ Demographic Characteristics } & \multicolumn{2}{|c|}{$\begin{array}{c}\text { Unsatisfactory } \\
(\mathrm{n}=263)\end{array}$} & \multicolumn{2}{|c|}{$\begin{array}{c}\text { Satisfactory } \\
(\mathrm{n}=159)\end{array}$} & \multirow[t]{2}{*}{$\mathrm{X}^{2}$} & \multirow[t]{2}{*}{$\mathrm{P}$ - value } \\
\hline & No. & $\%$ & No. & $\%$ & & \\
\hline \multicolumn{7}{|l|}{ Age / years } \\
\hline $18-19$ & 114 & 43.3 & 17 & 10.7 & \multirow[t]{3}{*}{50.944} & \multirow[t]{3}{*}{$0.0001^{*}$} \\
\hline $20-21$ & 122 & 46.4 & 108 & 67.9 & & \\
\hline $22-23$ & 27 & 10.3 & 34 & 21.4 & & \\
\hline \multicolumn{7}{|l|}{ Sex } \\
\hline Male & 71 & 27.0 & 38 & 23.9 & \multirow[t]{2}{*}{496} & \multirow[t]{2}{*}{0.481} \\
\hline Female & 192 & 73.0 & 121 & 76.1 & & \\
\hline \multicolumn{7}{|l|}{ Academic years } \\
\hline 1 st year & 99 & 37.6 & 8 & 5.0 & \multirow[t]{4}{*}{57.054} & \multirow[t]{4}{*}{$0.0001 *$} \\
\hline 2nd year & 59 & 22.4 & 56 & 35.2 & & \\
\hline 3rd year & 57 & 21.7 & 59 & 37.1 & & \\
\hline 4th year & 48 & 18.3 & 36 & 22.6 & & \\
\hline \multicolumn{7}{|l|}{ Residence } \\
\hline Urban & 89 & 33.8 & 43 & 27.0 & \multirow[t]{2}{*}{2.129} & \multirow[t]{2}{*}{0.145} \\
\hline Rural & 174 & 66.2 & 116 & 73.0 & & \\
\hline
\end{tabular}

Table (5): shows that there was highly statistically significant difference between the studied nursing students' knowledge and their age ( $\mathrm{p}$ value $<0.0001)$ as $21.4 \%$ of those who had a satisfactory knowledge level were in age group (22-23 years) versus $10.3 \%$ who had an unsatisfactory knowledge level.

Also, there was a statistical significant difference between different academic years and their knowledge level as by increasing the academic year, the knowledge level increase $(\mathrm{p}=0.0001)$.

Table (6): Relations between the studied nursing students' attitude and their demographic data (n=422).

\begin{tabular}{|c|c|c|c|c|c|c|}
\hline \multirow[t]{2}{*}{ Demographic Characteristics } & \multicolumn{2}{|c|}{$\begin{array}{c}\text { Negative } \\
(\mathrm{n}=41)\end{array}$} & \multicolumn{2}{|c|}{$\begin{array}{l}\text { Positive } \\
(\mathrm{n}=381)\end{array}$} & \multirow[t]{2}{*}{$\mathrm{X}^{2}$} & \multirow[t]{2}{*}{$\mathrm{P}-$ value } \\
\hline & No. & $\%$ & No. & $\%$ & & \\
\hline \multicolumn{7}{|l|}{ Age / years } \\
\hline $18-19$ & 16 & 39.0 & 115 & 30.2 & \multirow[t]{3}{*}{1.488} & \multirow[t]{3}{*}{.475} \\
\hline $20-21$ & 19 & 46.3 & 211 & 55.4 & & \\
\hline $22-23$ & 6 & 14.6 & 55 & 14.4 & & \\
\hline \multicolumn{7}{|l|}{ Sex } \\
\hline Male & 15 & 36.6 & 94 & 24.7 & \multirow[t]{2}{*}{2.742} & \multirow[t]{2}{*}{.098} \\
\hline Female & 26 & 63.4 & 287 & 75.3 & & \\
\hline \multicolumn{7}{|l|}{ Academic years } \\
\hline 1st year & 14 & 34.1 & 93 & 24.4 & \multirow[t]{4}{*}{5.898} & \multirow[t]{4}{*}{.117} \\
\hline 2nd year & 5 & 12.2 & 110 & 28.9 & & \\
\hline 3rd year & 14 & 34.1 & 102 & 26.8 & & \\
\hline 4th year & 8 & 19.5 & 76 & 19.9 & & \\
\hline \multicolumn{7}{|l|}{ Residence } \\
\hline Urban & 11 & 26.8 & 121 & 31.8 & \multirow[t]{2}{*}{.418} & \multirow[t]{2}{*}{.518} \\
\hline Rural & 30 & 73.2 & 260 & 68.2 & & \\
\hline
\end{tabular}


Table (6): presents that there was no statistically significant difference between the studied nursing students' attitude and their demographic data.

Table (7): Relations between the studied nursing students total knowledge levels and their attitude $(n=422)$.

\begin{tabular}{|c|c|c|c|c|c|c|}
\hline \multirow{3}{*}{ Attitude } & \multicolumn{4}{|c|}{ Knowledge } & \multirow{3}{*}{$\mathrm{X}^{2}$} & \multirow{3}{*}{$\mathrm{P}$ - value } \\
\hline & \multicolumn{2}{|c|}{$\begin{array}{l}\text { Unsatisfactory } \\
(n=263)\end{array}$} & \multicolumn{2}{|c|}{$\begin{array}{c}\text { Satisfactory } \\
(\mathrm{n}=159)\end{array}$} & & \\
\hline & No. & $\%$ & No. & $\%$ & & \\
\hline Negative $(\mathrm{n}=41)$ & 34 & 12.9 & 7 & 4.4 & 8.211 & $.004 * *$ \\
\hline Positive $(n=381)$ & 229 & 87.1 & 152 & 95.6 & & \\
\hline
\end{tabular}

$* *$ Highly significant $\mathrm{P}<0.01$

Table (7): cleared that there was highly statistically significant difference between the studied nursing students' knowledge and their attitude toward blood donation as $95.6 \%$ of those who had a satisfactory knowledge level had positive attitude versus $12.9 \%$ of those who had unsatisfactory knowledge level had negative attitude.

\section{Discussion}

Blood donation is life saving and useful in surgery, accidents, delivery cases, bleeding peptic ulcer, liver diseases, lung diseases, cancer, burn cases and blood diseases such as hemophilia, anemia, thalassemia but some of the patients needing transfusion do not receive timely access to safe blood. Safe blood donor is a blood donor who donates blood voluntarily, without knowing the beneficiary, without any expectation and without being under pressure of a direct or indirect nature (Kurian \& Sarkar, 2016).

Regarding mean age of the studied nursing students, it is $20.05 \pm 1.3$ years. This result was in the same line with a recent study done by Chauhan, Kumar and Thakur (2018) determined the knowledge, attitude and practices (KAP) of Dr rpamc Tanda in Himachal Pradesh about voluntary blood donation conducted among undergraduate medical students in India showed that the mean age being $20.42 \pm 1.38$ years.

Concerning gender of the studied nursing students, three quarters of them was female students. This result was in the same line with a recent study done by Cicolini et al., (2019) investigated factors involved in the blood donation (BD) in a population of Italian nursing students mentioned that three quarters of participants was female nursing students.

Regarding previous history of blood donation among the studied nursing students the current study found that the majority of them don't donate blood previously and about three quarters of nursing students who donates donated one time only. This result was agreement line with a recent study done by Kanani et al. (2018) compared the reasons for blood donation and knowledge about blood donation among medical science undergraduate students in Jamnagar and it showed that $80.0 \%$ of them never donated blood previously. Also, study done by Verma, et al. (2018) assessed knowledge, attitude, and practice towards blood donation and its associated factors among undergraduate medical students at Netaji Subash Chandra Bose medical college Jabalpur presented that $83.5 \%$ of students never donated blood, but this result contradicted to a recent study done by Cicolini et al. (2019) mentioned that near to two third of Italian nursing students ever donated blood previously and more than one third of donated Italian nursing students donated five times and more.

Concerning causes of non- blood donation among the studied nursing students nursing students more than one third of them said due to anemia, followed by thy didn't have a chance to donate and then near to one quarter of them fear from needle and infection. This result was in accordance with a recent study done by Govindasamy, Sivasankaran, and Purushothaman (2019) determined knowledge, attitude and practice regarding blood donation among medical students of government Thiruvannamalai Medical College in Tamil Nadu, India, found that $36.0 \%$ of them don't donated blood because they suffered from anemia also, Andsoy et al. (2016) determined the relationship between the knowledge, attitude and behaviors of the Turkish nursing students towards blood donation and their emphatic tendencies at School of Health in Karabuk University stated that $31.1 \%$ of the Turkish nursing students are reluctant to donate blood due to the pain caused by injection and the fear from faint. but this result contradicted with a recent study done by Verma et al. (2018) showed that most common reason of non-donation of blood among medical students was lack of awareness regarding when and where to donate blood, which constitute about 50.5 $\%$. Second most common reason was fear of pain and discomfort which constitute about $19.1 \%$ while $13.9 \%$ of the students said they never got an opportunity to donate blood. Reasons like family discouragement, busy life, concern about sterility of equipment's were also noted.

Regarding number of donation, about three quarters of the studied nursing students donated once and nearly two third of them mentioned that the main cause of blood donation was to help the people. This result in the same line with AlAsadi and Al-Yassen (2018) who evaluated the knowledge and attitude of two colleges in Basrah University students in Iraq about blood donation. It was found that $64.7 \%$ of Medicine and College of Administration and Economy students donated only once and among $74.5 \%$ of them the main cause of donation was moral satisfaction.

Regarding the studied nursing students' knowledge level more than one third $(37.7 \%)$ of them had satisfactory knowledge about blood donation. This result was lower than what found by Mulatu et al. (2017) who assessed the knowledge, attitude and practice of blood donation among residents of Aman Sub-City, South West Ethiopia they mentioned that $76.0 \%$ of total respondents had good knowledge while $14.0 \%$ only had poor knowledge. but a recent study done by Melku. et al. (2018) found that 51.6\% of undergraduate health science students had inadequate knowledge. This difference may be due to when the authors scored students' knowledge calculated $70.0 \%$ and above had adequate knowledge while in these results calculated $60.0 \%$ and above had adequate knowledge

Also, this result contradicted with Bharatwaj, Vijaya, and Rajaram (2012) find out the knowledge, attitude and the practice with regards to voluntary blood donations of the 280 students of second and third MBBS at the Sri Lakshminarayana Institute of Medical Sciences which is 
located in Pondicherry, India concluded that all the participants had an incomplete knowledge regarding the various aspects of voluntary blood donation. This difference related to medical collages did not study any topics related to blood donation so they hadn't knowledge about it.

Concerning the studied nursing students' attitude more than one third of them had positive attitude about readiness to donate continuously in the future. This result was in the same line with Andsoy et al. (2016) who found that $40.0 \%$ of Turkish nursing students stated that they were willing to donate blood.

The present study more than three quarters of the studied nursing students had positive attitude about encouraging the volunteer to donate blood. This result was in the same line with a recent study Melku. etal. (2018) mentioned that $89 \%$ of undergraduate health science students were encouraged others to donate blood.

Regarding the studied nursing students' attitude, the majority of them had positive attitude towards blood donation. This result was in the same line with a recent study done by Alsalmi et al. (2019) reported that the majority of the health professions students in Saudi Arabia delivered a positive attitude regarding blood donation and Melku. et al. (2018) mentioned that $79.2 \%$ of undergraduate health science students had positive attitude regarding blood donation.

Regarding the relation between the studied nursing students' total knowledge levels with their age in which students aged between 20-21 years were more knowledgeable than who aged between $18-19$ year with statistically significance differences. This result was in the same line with Verma et al. (2018) who showed that medical students belongs to $>20$ years of age group has significantly more knowledge regarding blood donation $(\mathrm{P}<0.001)$ when compared with the students belongs to the 17-20 years of age group.

Regarding relations between the studied nursing students' total knowledge levels with their gender and residence; there was not statistically significance differences. This result in the same line with a recent study done by Melku., et al., (2018) who showed that gender and residence were not associated with undergraduate health science student's knowledge. also, Govindasamy, Sivasankaran, and Purushothaman (2019) mentioned that sex failed to prove a significant association with blood donation, but this result was inconsistence with a recent study done by Verma et al., (2018) showed that medical female students when compared with male have more knowledge and good attitude regarding blood donation.

Regarding the relation between the studied nursing students' total knowledge levels with their academic years in which $3^{\text {rd }}$ year student more knowledgeable than other academic year with statistically significance differences. This result was in the same line with a recent study done by Alsalmi et al. (2019) who showed an increase in the donation knowledge over progression in the academic years.

Regarding the relation between the studied nursing students' attitude with their age; there was not statistically significance difference. This result was inconsistence with Govindasamy, Sivasankaran, and Purushothaman (2019) who revealed that age had a significant association with attitude towards blood donation. Those $\geq 21$ years had a positive attitude towards blood donation. Also, Verma et al., (2018) showed that medical students belong to $>20$ years of age group has significantly good attitude regarding blood donation $(\mathrm{p}<0.001)$ when compared with the students belongs to the 17-20 years of age group.

Regarding relations between the studied nursing students' attitude with their gender and residence; there were not statistically significant differences. This result was in the same line with a recent study done by Melku. et al. (2018) who showed that gender and residences not associated with undergraduate health science students' attitude, but this result was inconsistence with Govindasamy, Sivasankaran, and Purushothaman (2019) who revealed that sex had a significant association with attitude towards blood donation. The female sex had a more negative attitude and outlook towards donation of blood.

Concerning the relation between the studied nursing students's total knowledge levels and their attitude there was statistically significant difference between the studied nursing students' knowledge and their attitude toward blood donation. This result was in the same line with Verma et al. (2018) who presented that medical student there was statistical significance difference between medical students' knowledge and their attitude about blood donation.

\section{Conclusion}

Based on the results of the present study, can be concluded that:

About one third of the studied nursing students had satisfactory knowledge level about blood donation and the majority of them had positive attitude about blood donation. Also, there was statistically significant difference between the studied nursing students' knowledge with their age, academic years and their attitude towards blood donation.

\section{Recommendations}

Based on results of the present study the following can be recommended that:

- Increase knowledge of nursing students about blood donation through making seminars and workshop about it.

- Introduce a lecture in the curricula taught for first year students about donating blood.

- Encourage the implementation of future educational program for students in all faculties to increase their knowledge and positive attitudes toward blood donation.

- Future studies should focus on the other students in other faculties.

\section{References}

(1) Al-Asadi, J. N., \& Al-Yassen, A. Q. (2018). Knowledge, attitude and practice of blood donation among university students in Basrah, Iraq: A comparison between medical and non-medical students. Asian Journal of Medical Sciences, 9(6), 62-67.

(2) Al-Haqqan, T., Husain, A., Al-Kandari, N., Al-Rashidi, L., AlDaihani, N., \& Mitra, A. K. (2016). A Cross-Sectional Study of Knowledge, Attitude, Practice, and Barriers Regarding Blood Donation among General Population in Kuwait. International Journal of Community \& Family Medicine, 2016.

(3) Al-Mutairi, M. A., Al-Nazzawi, A.-A. O., Al-Rehaili, S. H., AlRahili, N. H., Al-Johani, W. A., \& Al-Suhaymi, I. A. (2015). Knowledge and intentions toward blood donation among medical students of Taibah University, Madinah, Saudi Arabia 2015.

(4) Alsalmi, M. A., Almalki, H. M., Alghamdi, A. A., \& Aljasir, B. A. (2019). Knowledge, attitude and practice of blood donation among health professions students in Saudi Arabia; A cross-sectional study. Journal of family medicine and primary care, 8(7), 2322.

(5) Andsoy, I. I., Gul, A., \& Dinc, S. (2016). Comparing the Attitudes and Behaviors of Turkish Nursing Students towards Blood 
Donation and Their Emphatic Tendencies. International Journal of Caring Sciences, 9(1).

(6) Bharatwaj, R., Vijaya, K., \& Rajaram, P. (2012). A descriptive study of knowledge, attitude and practice with regard to voluntary blood donation among medical undergraduate students in Pondicherry, India. J Clin Diagn Res, 6(4), 602-604.

(7) Chauhan, R., Kumar, R., \& Thakur, S. (2018). A study to assess the knowledge, attitude, and practices about blood donation among medical students of a medical college in North India. Journal of family medicine and primary care, 7(4), 693.

(8) Cicolini, G., Comparcini, D., Alfieri, S., Zito, E., Marta, E., Tomietto, M., \& Simonetti, V. (2019). Nursing students' knowledge and attitudes of blood donation: A multicentre study. Journal of clinical nursing, 28(9-10), 1829-1838.

(9) Elias, E., Mauka, W., Philemon, R. N., Damian, D. J., Mahande, M. J., \& Msuya, S. E. (2016). Knowledge, attitudes, practices, and factors associated with voluntary blood donation among university students in Kilimanjaro, Tanzania. Journal of blood transfusion, 2016.

(10) Frasiska N. Suprijatna E., and Susanti S., (2016). Effect of Diet Containing Gracilaria Sp. Waste and Multi-Enzyme Additives on Blood Lipid Profile of Local Duck. Animal Production. 18(1):22-29.

(11) Goda, S. M. (2017). Assessment of Knowledge and Attitude About Blood Donation among Nursing Students at Assiut University. Assiut Scientific Nursing Journal, 5(11), 26-36.

(12) Govindasamy, V., Sivasankaran, D., \& Purushothaman, V. (2019). Knowledge, attitude and practice regarding blood donation among medical students of Tamil Nadu-a cross sectional study. International Journal of Community Medicine And Public Health, $6(10), 4583$

(13) Kanani, A. N., Vachhani, J. H., Upadhyay, S. B., \& Dholakiya, S. K. (2018). A study on knowledge and awareness about blood donation amongst government medical, para-medical and nursing undergraduate students in Jamnagar, Gujarat. Global Journal of Transfusion Medicine, 3(1), 46.

(14) Kurian, R. N., \& Sarkar, S. (2016). Study to assess the Knowledge and Attitude regarding Blood Donation among the General Public in a Selected Urban Area of New Delhi. Int. J. Nurs. Midwif. Res, 3(1), 30-34.

(15) Melku, M., Asrie, F., Shiferaw, E., Woldu, B., Yihunew, Y., Asmelash, D., \& Enawgaw, B. (2018). Knowledge, Attitude and Practice Regarding Blood Donation among Graduating Undergraduate Health Science Students at the University of Gondar, Northwest Ethiopia. Ethiopian journal of health sciences, 28(5).

(16) Mulatu, K., Hailu, T., Yegezu, A., \& Tena, B. (2017). Assesment of knowledge, attitude and practice on blood donation in Aman sub city residents, South West, Ethiopia, 2015. Health Science Journal, 11(1), 1.

(17) Nataba, A. (2019). Challenges to blood donor notification on transfusion transmissible infections: a case study of Lodwar County and Referal Hospital Blood Bank Satelite. Strathmore University.

(18) Razdan, N., Kumar, R., Bhardwaj, A., \& Singh, P. (2018). The knowledge, attitude, and practice toward blood donation among voluntary and replacement blood donors in Ambala, India. International Journal of Medical Science and Public Health, 7(6), 444-452.

(19) Singh, S., Muninarayana, C., Venkatesha, M., \& Anil, N. (2015). Blood donation awareness and beliefs among medical and nursing students. Int J Med Sci Public Health, 4(10), 1338-1342.

(20) Tadesse, W., Ayalew, Y., Yisma, E., Liben, M. L., \& Wudu, M. (2018). Knowledge, Attitude, Practice and Associated Factors towards Voluntary Blood Donation among Regular Health Science Students of Samara University, Ethiopia. Health Science Journal, 12(1).

(21) Ugwu, N., Oti, W. O., Ugwu, C., \& Uneke, C. (2019). Voluntary non-remunerated blood donation: Awareness, perception, and attitude among potential blood donors in Abakaliki, Nigeria. Nigerian journal of clinical practice, 22(11), 1509.

(22) Verma, P., Thakur, A., Saklecha, D., \& Kasar, P. K. (2018). A cross sectional study to assess knowledge, attitude and practice regarding voluntary blood donation among medical students of Jabalpur, central India. International Journal of Community Medicine And Public Health, 5(3), 963-969 